\section{More comments on Amphyginus Haliday, 1841 (Coleoptera, Carabidae, Calathus)}

nus Iberocalathus to include $C$. rotundatus on a morphological and geographic basis. Hence, this new subgenus should be included in future editions of the catalogues mentioned above.

\section{ACKOWLEDGEMENTS}

This paper has been supported by project $00595 / \mathrm{PI} / 04$ of the Fundación Séneca, Consejería de Educación de Murcia.

\section{References}

Alonso-Zarazaga, M. A., 2006. Amphyginus Haliday, 1841 has precedence over Neocalathus Ball \& Nègre, 1972 (Coleoptera, Carabidae). Graellsia, 62(2): 265.

Freude, H., 1976. 1. Familie: Carabidae (Laufkäfer). In: H. Freude, K. W. Harde \& G. A. Lohse (eds.). Die Käfer Mitteleuropas. Band 2, Adephaga 1. Goecke \& Evers, Krefeld. 302 pp.

Hovorka, O. \& ScIaky, R., 2003. Subtribe Calathina Laporte 1934. In: I. Löbl \& A. Smetana (eds.). Catalogue of Palaearctic Coleoptera. Vol. 1. Archostemata, Myxophaga, Adephaga. Apollo Books. Stenstrup: 524-529.

Jeannel, R., 1941. Coléoptères Carabiques. Faune de France, 40: 572-1173. Lechevalier, París.

LiNDROTH, C. H., 1976. Handbooks for the identification of British Insects. IV, part II. Royal Entomological Society, London

Lorenz, W., 1998. Nomina Carabidarum. A directory of the scientific names of ground beetles (Insecta, Coleoptera "Geadephaga": Trachypachidae and Carabidae incl. Paussinae, Cicindelinae, Rhysodinae). 1st ed. Edited by the author. Tutzing. 937 pp.

LoRenz, W., 2005. Nomina Carabidarum. A directory of the scientific names of ground beetles (Insecta, Coleoptera "Geadephaga": Trachypachidae and Carabidae incl. Paussinae, Cicindelinae, Rhysodinae). 2nd ed. Edited by the author. Tutzing. 993 pp.

Ruiz, C. \& Serrano, J., 2006. Molecular phylogeny and systematics of Calathus Bonelli (Coleoptera: Carabidae: Sphodrini) based on mitochondrial cox1cox2 sequences. Entomologica Fennica, 17: 214-220.

Toribio, M., 2006. Notas sobre el género Calathus Bonelli, 1810, en la Península Ibérica (Coleoptera, Carabidae). Bulletin de la Société entomologique de France, 111: 51-57.
The molecular study has also shown that Amphyginus includes only the type species $C$. rotundicollis Dejean, 1828. The recent Palearctic catalogue mentioned above includes the Iberian species C. rotundatus Jacquelin du Val, 1857 in this subgenus, but the supposed close relatedness between both species is not warranted on molecular grounds (Ruiz \& Serrano, 2006). Furthermore, Toribio (2006) has created the monobasic subge-
Recibido, 24-I-2007

Aceptado, 28-V-2007

Publicado, 27-VI-2007 